\title{
Identification of a Splicing Coactivator Gene that Affects the Production of Ochratoxin A in Aspergillus carbonarius
}

\author{
Lígia Uno Lunardi ${ }^{1}$, Roberta Losi Guembarovski ${ }^{1}$, Luiz Ricardo Hanai ${ }^{2}$, Valderi \\ Cristiano $^{3}$, Maria Lucia Carneiro Vieira ${ }^{2}$, Daniele Sartori ${ }^{1}$ and Maria Helena Pelegrinelli \\ Fungaro $^{1 *}$ \\ ${ }^{1}$ Centro de Ciências Biológicas; Universidade Estadual de Londrina; C. P.: 6001; 86055-900; Londrina - PR - \\ Brasil. ${ }^{2}$ Escola Superior de Agricultura Luiz de Queiroz; Universidade de São Paulo; C. P.: 83; 13400-970; \\ Piracicaba - SP - Brasil. ${ }^{3}$ Centro de Ciências Exatas; Universidade Estadual de Londrina; C. P.: 6001; 86055-900; \\ Londrina - PR - Brasil
}

\begin{abstract}
Ochratoxin A is a mycotoxin produced by some fungi species. Among them, Aspergillus carbonarius is considered a powerful producer. Genes involved in the ochratoxin A biosynthesis pathway have been identified in some producer species. However, there are few studies that purpose to identify these genes in A. carbonarius. The use of insertion mutants to identify genes associated with certain properties has been increased in the literature. In this work, the region of T-DNA integration was investigated in one A. carbonarius ochratoxin-defective mutant previously obtained by Agrobacterium tumefaciens-mediated transformation, in order to find an association between interrupted gene and the biosynthesis of ochratoxin A. The integration occurred in a gene that possibly encodes a splicing coactivator protein. The analysis of the relative expression of the splicing coativator gene from A. carbonarius wild type strain in four different media showed high correlation between the transcript levels and the ochratoxin A production.
\end{abstract}

Key words: ochratoxigenic fungi, mycotoxin, real time PCR, splicing coactivator protein

\section{INTRODUCTION}

Ochratoxin A (OTA) is a toxin produced by some fungal species, known to have nephrotoxic effects and carcinogenic potential. This mycotoxin has been found in grapes and grape products such as juice, wine, and dried vine fruit (Zimmerli and Dick, 1996; Macdonald et al., 1999; Majerus et al., 2000; Da Rocha Rosa et al., 2002; Valero et al., 2005). Due to the potential for human and animal health hazard, the European Union (EU) has introduced maximum limits for OTA in dried vine fruits $\left(10 \mu \mathrm{g} \mathrm{kg}^{-1}\right)$ and wine $\left(2 \mu \mathrm{g} \mathrm{kg}^{-1}\right)$. OTA has also been found in market samples of roasted coffee (Fujii et al., 2007). By the same token, the EU (European Commission, 2005) established limit of OTA in roasted $\left(5 \mu \mathrm{g} \mathrm{kg}^{-1}\right)$ and soluble (10 $\mu \mathrm{g} \mathrm{kg}^{-1}$ ) coffees. The results of several years of investigation to recognize whose fungi were responsible for the OTA production in coffee and grapes showed that Aspergillus carbonarius is one

\footnotetext{
* Author for correspondence: fungaro@uel.br
} 
of the most important species (Taniwaki et al., 2003).

OTA is a polyketide-derived secondary metabolite consisting of chlorinated isocoumarin derivative linked to L-phenylalanine (Moss, 1996). O'Callaghan and Dobson (2006a) reviewed the biosynthesis of this mycotoxin and results suggest it is a process consisting of four main steps: (1) biosynthesis of the pentaketide 7-methyl-mellein by a PKS (polyketide synthase); (2) oxidation by cytochrome $\mathrm{P} 450$ to produce the intermediate 7 carboxy-mellein; (3) chlorination, probably by a chloroperoxidase producing 7-carboxy-5-chloromellein, and (4) the condensation of this intermediary with phenylalanine by the OTA synthase, probably a non-ribosomal peptide synthase. Some structural genes were already identified as related to OTA biosynthesis in Aspergillus ochraceus and Penicillium species (O'Callaghan et al., 2003; Geisen et al., 2004; Karolewiez and Geisen, 2005; Atoui et al., 2006; Bogs et al., 2006). More recently, a structural gene (a pks gene) possibly involved in the OTA biosynthesis in A. carbonarius was reported (Gallo et al., 2009). However, as far as we know, genes involved in the regulation of the structural ochratoxin gene were not described until now for none of the ochratoxigenic species.

The T-DNA insertional mutagenesis approach is a powerful tool for detecting genes involved in a particular function. This strategy is based on the capability of Agrobacterium tumefaciens to transform host genomes by transferring its T-DNA to the host nuclei. The exogenous sequence is able to insert itself at random within chromosomes (Azpiroz-Leehan and Feldmann, 1997), and therefore can be used as a mutagen to create lossof-function mutations in several organisms. The TDNA not only disrupts the gene where it is inserted, but also acts as a marker for subsequently identifying the mutation. This approach has been used for cloning genes, promoters, and regulatory sequences (Radhamony et al., 2005). Bundock et al. (1995) firstly described the protocols for the transference of T-DNA into fungi cells. Only recently, the Agrobacterium-mediated transformation (AMT) protocol was adapted to transform A. carbonarius and used for generating insertional mutants (Morioka et al., 2006; Lunardi et al., 2006).

In this contribution, we verified the integration of T-DNA in one $A$. carbonarius ochratoxindefective mutant obtained by AMT, and identified a gene which was probably involved in the regulation of OTA biosynthesis.

\section{MATERIALS AND METHODS}

\begin{abstract}
Strains
Aspergillus carbonarius wild type (ITAL187) used in the present study was obtained from coffee beans and kindly provided by Taniwaki et al. (2003). The mutant T188 was obtained by using Agrobactrium-mediated transformation approach by Lunardi et al. (2006). This mutant produces significantly lower amounts of OTA than the wild type strain after growing for four days on YES medium.
\end{abstract}

\section{DNA and RNA extraction}

Genomic DNA of A. carbonarius T188 mutant and wild type strain ITAL187 was extracted according to Azevedo et al. (2000) and quantified by a fluorimetric method (Dyna Quant, Phamarcia). Total RNA was extracted using Trizol reagent (Invitrogen) following the manufacturer's instructions.

\section{Southern blot analysis}

DNA digestion was performed using $S s t \mathrm{I}$ that cuts the expression cassette once, outside of the $h p h$ gene. Standard procedures described in Sambrook and Russell (2001) was used for restriction endonuclease digestion, agarose-electrophoresis, and transference onto nylon membranes. Approximately $5 \mu \mathrm{g}$ of digested genomic DNA were submitted to electrophoresis in each track. As a probe, a fragment of the $h p h$ gene $(0.6 \mathrm{~kb})$ was used. This fragment was obtained by PCR using the primer pair hph1 (5'TTCGATGTAGGAGGGCGTGGAT) and hph2 (5'-CGCGTCTGCTGCTCCATACAAG). DNA probe labeling and hybridization were performed using a digoxigenin (DIG) hybridization system (Roche) according to the manufacturer's recommendations.

\section{Identification of DNA sequences flanking T- DNA insertions}

The T-DNA flanking region was extended by using an adaptation of the PCR-walking methodology as described by Cottage et al. (2001). Following the manufacturer's instructions, genomic DNA (100 ng) was partially digested for $3 \mathrm{~h}$ at $37^{\circ} \mathrm{C}$ with $5 \mathrm{U} S s p \mathrm{I}$, a blunt-cutting 
restriction enzyme (New England Biolabs) in a final volume of $25 \mu \mathrm{L}$. Adapters were prepared by mixing equimolar amounts of the oligonucleotides 5'-ACTCGATTCTCAACCCGAAAGTATAGAT CCCA and 5'-TGGGATCTATACTT (with 3' amino group), which were ligated to the bluntended fragments for $3 \mathrm{~h}$ at $17^{\circ} \mathrm{C}$. The reaction was performed by adding an equal volume of a ligation solution i.e. $30 \mathrm{mM}$ Tris- $\mathrm{HCl}(\mathrm{pH} 7.5), 10 \mathrm{mM}$ $\mathrm{MgCl}_{2}, 10 \mathrm{mM}$ DTT, $1.0 \mathrm{mM}$ ATP, $1 \mu \mathrm{M}$ adapters, and 1.2 units of T4 DNA ligase (New England Biolabs). The resulting products were diluted with ultra pure water and used as templates in the amplification reaction. A primer specific to the adaptor (5'ACTCGATTCTCAACCCGAAAG) and nested primers specific to T-DNA (RB1, RB2, RB3 or LB1, LB2, LB3) (Combier et al., 2003) were used to amplify the flanking region. The adapter sequence does not contain a primer-binding site, which is created only by the PCR extension from the walking-primer (Fig. 1). In order to obtain greater specificity, PCR products were submitted to two semi-nested-PCRs using internal primers i.e. RB2 and RB3 or LB2 and LB3 combined with the primer specific to the adapter. The final PCR products were resolved on agarose gels, purified (QIA quick ${ }^{\circledR}$ Kit, Qiagen) and cloned (TOPO TA Cloning for Sequencing Kit, Invitrogen). Cloned inserts were sequenced with DYEnamic ${ }^{\mathrm{TM}} \mathrm{ET}$ dye Terminator Cycle Sequencing kit (Amersham Pharmacia Biotec, Inc.) for MegaBace 1000. By using the BLASTX and BLASTN algorithm (Altschul et al., 1997), the resulting sequences were searched against Aspergillus niger genome (http://genome.jgipsf.org/Aspni1/Aspni1.home.html) and others (http://blast.ncbi.nlm.nih.gov/Blast.cgi).

\section{Characterization of the T-DNA integration by PCR}

Based on the two regions flanking the T-DNA (left and right borders), a primer-pair was designed to characterize the supposed deletion caused by the T-DNA integration. One primer sequence recognized the F-actin gene (5'CGATGAAGGAGGATGCGAGT), and the other one recognized the splicing coactivator gene (5'CACCACCCCTGATGAACCG). This primer pair was used to amplify DNA from the T188 mutant and the wild type strain ITAL187. The PCR was performed in a total volume of $100 \mu \mathrm{L}$ containing DNA $5 \mathrm{ng}, 1.5 \mathrm{mM} \mathrm{MgCl} 2,0.2 \mathrm{mM}$ dNTP, PCR buffer 1x (Invitrogen), $0.5 \mu \mathrm{M}$ primer, $1 \mathrm{U}$ Taq DNA polymerase (Invitrogen). The amplification conditions used were $5 \mathrm{~min} 94^{\circ} \mathrm{C}, 30$ cycles $(45 \mathrm{~s}$ $94^{\circ} \mathrm{C}, 1 \mathrm{~min} 62^{\circ} \mathrm{C}, 1 \mathrm{~min}$ and $15 \mathrm{~s} 72^{\circ} \mathrm{C}$ ) and $5 \mathrm{~min}$ $72^{\circ} \mathrm{C}$. An aliquot of PCR products was separated by electrophoresis in $0.8 \%$ agarose gels and visualized by ethidium bromide staining. The remaining reaction mixture was purified and submitted to sequencing on MegaBace 1000 as described above.

\section{Kinetic study of ochratoxin A production}

For a kinetic study of the OTA production by the ITAL 187 strain, conidia were inoculated at a density of $10^{6} \mathrm{~mL}^{-1}$ into $500-\mathrm{mL}$ flasks containing $100 \mathrm{~mL}$ of permissive liquid medium (CY). The flasks were incubated in the dark at $25^{\circ} \mathrm{C}$ for up to 10 days. After 2, 4, 6, 8, and 10 days, the OTA content in culture broths was measured by high performance liquid chromatography (HPLC). OTA extraction and purification was done according to OCHRAPREP $^{\circledR}$-Quantitative Detection of Ochratoxin A (R-Biopharm Ltd) kit instruction. A LC-10VP HPLC system (Shimadzu) was used with fluorescence detection set at $333 \mathrm{~nm}$ excitation and $443 \mathrm{~nm}$ emissions. A Spherisorb ODS2 $(5 \mu \mathrm{m} \times 25 \mathrm{~cm} \times 5 \mathrm{~mm})$ column was employed. The mobile phase was an acetonitrilewater-acetic acid (51/47/2, v/v/v) mixture and the flow rate was $1 \mathrm{~mL} \mathrm{~min}^{-1}$. An OTA standard (Sigma) was used for the construction of a calibration curve, peak area versus concentration $\left(\mu \mathrm{g}^{-1}\right)$. The OTA concentration in sample extract was determined by the interpolation of peak area results from the calibration graph.

\section{RT-real time PCR analysis}

Firstly, the ITAL 187 strain was grown for sporulation at $25^{\circ} \mathrm{C}$ on potato dextrose agar for 5 days. Conidia (approximately $10^{6} \mathrm{~mL}^{-1}$ ) were inoculated into $100 \mathrm{~mL}$ of four different media: CY, YES, PD, and EMP. The $\mathrm{pH}$ of the media was adjusted to 5.0 by adding acetic acid. After growing in the dark for four days, the RNA was extracted using Trizol reagent (Invitrogen). 


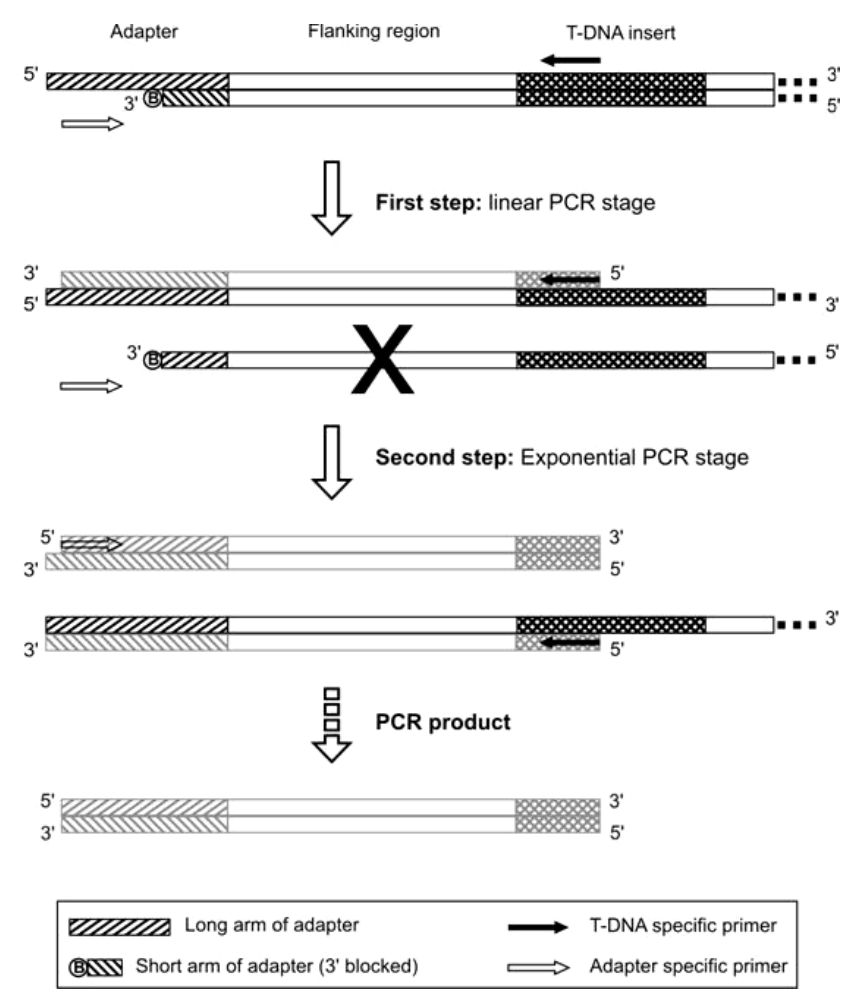

Figure 1 - Amplification scheme of PCR-walking method for identification of T-DNA flanking sequences. DNA was digested with a restriction enzyme and an adapter was ligated to the ends of the restriction fragments. This adapter has the 3' end of the short strand blocked by the presence of an amino group that prevents the extension with Taq DNA polymerase. The amplification of T-DNA flanking sequences involved a two-step PCR procedure. Although both T-DNA and adapter primers are in the PCR, a first step was carried out as a linear (asymmetric) PCR using only the specific primer to T-DNA (RB1 or LB1) because in this step the binding site to the adapter primer is not present. The adapter-binding site is generated after the extension from T-DNA primer that prevents amplification from adapter to adapter. In the second step, an exponential amplification was carried out using both T-DNA and adapter primers.

First-strand cDNA synthesis was performed with reverse transcriptase (RT M-MLV, Invitrogen) according to the manufacturer's protocol from 500 $\mu \mathrm{g}$ of total RNA. Real time PCRs were performed in a PTC 200 DNA Engine Cycler using a Chromo4 Detection System (MJ Research). The primers, 5'-CACCACCCCTGATGAACCG and 5'-GGGCTTCTTCGGTGTCGGA, respectively, were used as forward and reverse for expression analysis of the splicing coactivator gene by using RT-real time PCR. Platinum ${ }^{\circledR}$ SYBR $^{\circledR}$ Green qPCR Supermix-UDG (Invitrogen) was used as reaction mixture, adding $0.4 \mu \mathrm{M}$ of each primer and $2 \mu \mathrm{L}$ of template cDNA, in a final volume of $25 \mu \mathrm{L}$. The PCR thermal cycling conditions were as follows: an initial step at $95^{\circ} \mathrm{C}$ for $5 \mathrm{~min}$, and 40 cycles at $95^{\circ} \mathrm{C}$ for $20 \mathrm{~s}, 62^{\circ} \mathrm{C}$ for $15 \mathrm{~s}$, and $72^{\circ} \mathrm{C}$ for
$20 \mathrm{~s}$, followed by $95^{\circ} \mathrm{C}$ for $10 \mathrm{~s}$ and $40^{\circ} \mathrm{C}$ for 1 min. A melting curve analysis was persistently performed at the end of the reaction to check for primer-dimer artifacts and contamination. In addition, in all experiments, appropriate negative controls containing no template were subjected to the same procedure to exclude or detect any possible contamination. All experiments were performed with two replications. The values were normalized against the housekeeping gene glyceraldehyde-3-phosphate-dehydrogenase (G3PDH). The primers for amplification of cDNA for A. carbonarius G3PDH were g3pdh-bf (5'TCGTCAACGGCAAGAAGATT) and g3pdh-br (5'-TAGCAAGGGGAGCAAGGCAGT), as described by O'Callaghan et al. (2006b). The analysis of relative expression results in real time 
PCR was performed using the REST-MCS ${ }^{\odot}$ software (www.gene-quantification.info) (Pfaffl et al., 2002).

\section{RESULTS AND DISCUSSION}

The mutant denoted T188 that produces significantly less OTA $(1.6 \%)$ than the wild type strain $(100 \%)$ (ITAL 187) was investigated by using Southern analysis to detect the T-DNA copy number integrated into the genome. As shown in Figure 2, a single foreign DNA copy was found integrated in the T188 mutant genome, meaning that it is appropriate to look for associations between the gene disrupted by insertional mutagenesis and its phenotype. After PCR-based amplification of DNA fragments spanning insertion site borders and sequencing, the BLASTN and BLASTX algorithms was used to characterize the insertion of T-DNA within the host genome.

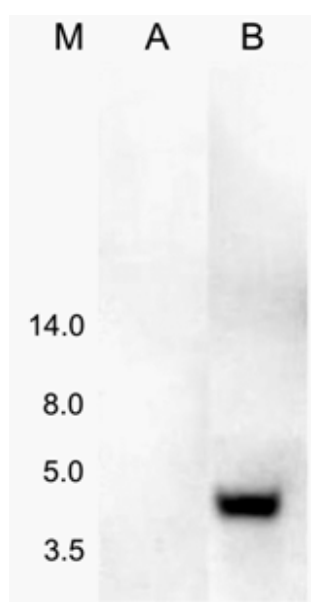

Figure 2 - Southern blot analysis of the Aspergillus carbonarius T188 mutant. Genomic DNA was digested with SstI and electrophoresed on a $0.8 \%$ agarose gel; for hybridization, a 0.6 $\mathrm{kb}$-fragment of the $h p h$ gene labeled with digoxegenin was used. M: molecular marker (Kb); A: Untransformed wild type strain (ITAL187); B: T188 mutant.

The nucleotide sequence flanking one side of the insertion site (left border, $1251 \mathrm{nt}$ ) showed significant similarity with the initial part of the locus An11g05460 from A. niger strain CBS $513.88\left(\mathrm{E}\right.$ value $\left.=2 \mathrm{e}^{-50}\right)$, which is annotated as encoding an F-actin subunit alpha protein. The nucleotide sequence flanking the other side of the insertion site (right border, $228 \mathrm{nt}$ ) showed high similarity with locus An11g05450 from the same A. niger strain CBS $513.88\left(\mathrm{E}\right.$ value $\left.=5 \mathrm{e}^{-47}\right)$, which is annotated as encoding a hypothetical protein (http://blast.ncbi.nlm.nih.gov/Blast.cgi). This same sequence was also searched for in the genome of the A. niger strain ATCC 1015 (http://genome.jgi-

psf.org/Aspni1/Aspni1.home.html). Equally significant nucleotide similarities were found $\left(2 \mathrm{e}^{-}\right.$ $\left.{ }^{39}\right)$, but in this case the gene is annotated as encoding an unnamed protein of 647 aa (ID 39109) with KOG description as a splicing coactivator SRm160/300, subunit SRm300, i.e. a protein involved in RNA processing and modification. When an exact joining of T-DNA and fungus genomic DNA takes place, sequences of the same gene are expected for both sides of the integrated T-DNA. Our results mean that a nonexact joining of T-DNA and fungus genomic DNA occurred during the integration event. Information on the pattern of T-DNA integration in fungi was very limited, with only a few T-DNA insertion sites having been characterized in several species transformed using A. tumefaciens (Bundock et al., 1995; Mullins et al., 2001; Leclerque et al., 2004, Choi et al., 2007; Li et al., 2007; Meng et al., 2007). The most significant contribution for understanding the mechanisms and characteristics 
of T-DNA integration has been given from analysis of Magnaporthe oryzae transformants. Choi et al. (2007) conducted a broad analysis of TDNA insertion sites in transformants of M. oryzae and showed that exact joining (without deletion, addition, and microhomology) of T-DNA and genomic DNA occurred in only $14.1 \%$ of the integration events. Non-exact joining of T-DNA and fungus genomic DNA occurred very frequently. The most frequent non-exact joining was that represented by a deletion of genomic DNA at the insertion site (78.3\%). Deletions of genomic DNA ranged from 1 to $1950 \mathrm{bp}$, most of them being less than $35 \mathrm{bp}$ (77.8\%), while those larger than 100 bp comprised only 9.8\%. In addition, small duplications (1-11 bp) and chromosomal translocations were also observed in $7.6 \%$ of integration events. Also studying $M$. oryzae, Li et al. (2007) showed that deletions due to T-DNA integration are found frequently in genomic target sites. Although small deletions (1$80 \mathrm{bp}$ in size) were more frequent, a deletion of $505 \mathrm{p}$ in size was found in one transformant. Equally, Meng et al. (2007) examined the junctions between chromosomal DNA and the left and right T-DNA borders in several $M$. oryzae transformants for possible deletions surrounding the target site. Among 36 informative T-DNA insertions, 34 exhibited a genomic deletion at the target site. Five of them were deletions larger than $1 \mathrm{~kb}$.

In order to confirm the deletion caused by T-DNA integration, we amplified the region between a portion of F-actin gene and a portion of splicing coactivator gene by using DNA from the wild type strain ITAL 187 and the mutant strain T188. As shown in Figure 3, the amplification products obtained were of $6040 \mathrm{bp}$ and $970 \mathrm{bp}$ from the insertional mutant (T188) and the wild type strain (ITAL 187), respectively.

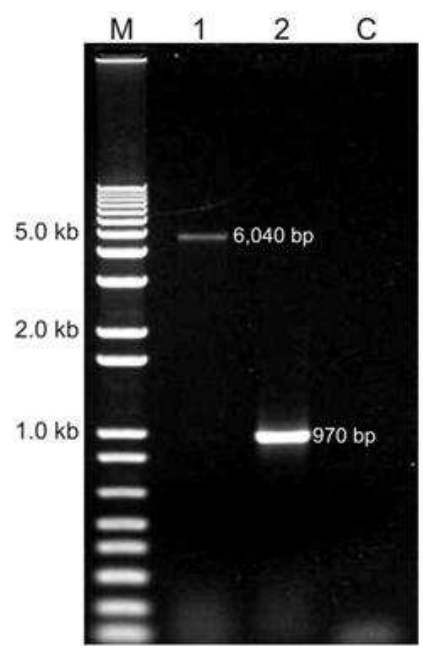

Figure 3 - Amplification of the region between splicing coactivator gene and F-actin gene in Aspergillus carbonarius wild type and mutant. M: 1kb molecular marker; Lane, 1: A. carbonarius T188 mutant; Lane, 2: A. carbonarius ITAL187 wild type; C: negative control.

The sequence analysis in fact showed that T-DNA integration into the mutant $\mathrm{T} 188$ provoked a deletion of $727 \mathrm{bp}$ in length. The deletion includes a final portion of the splicing coactivator gene and a non-coding region between this gene and the Factin gene (Fig. 4). 


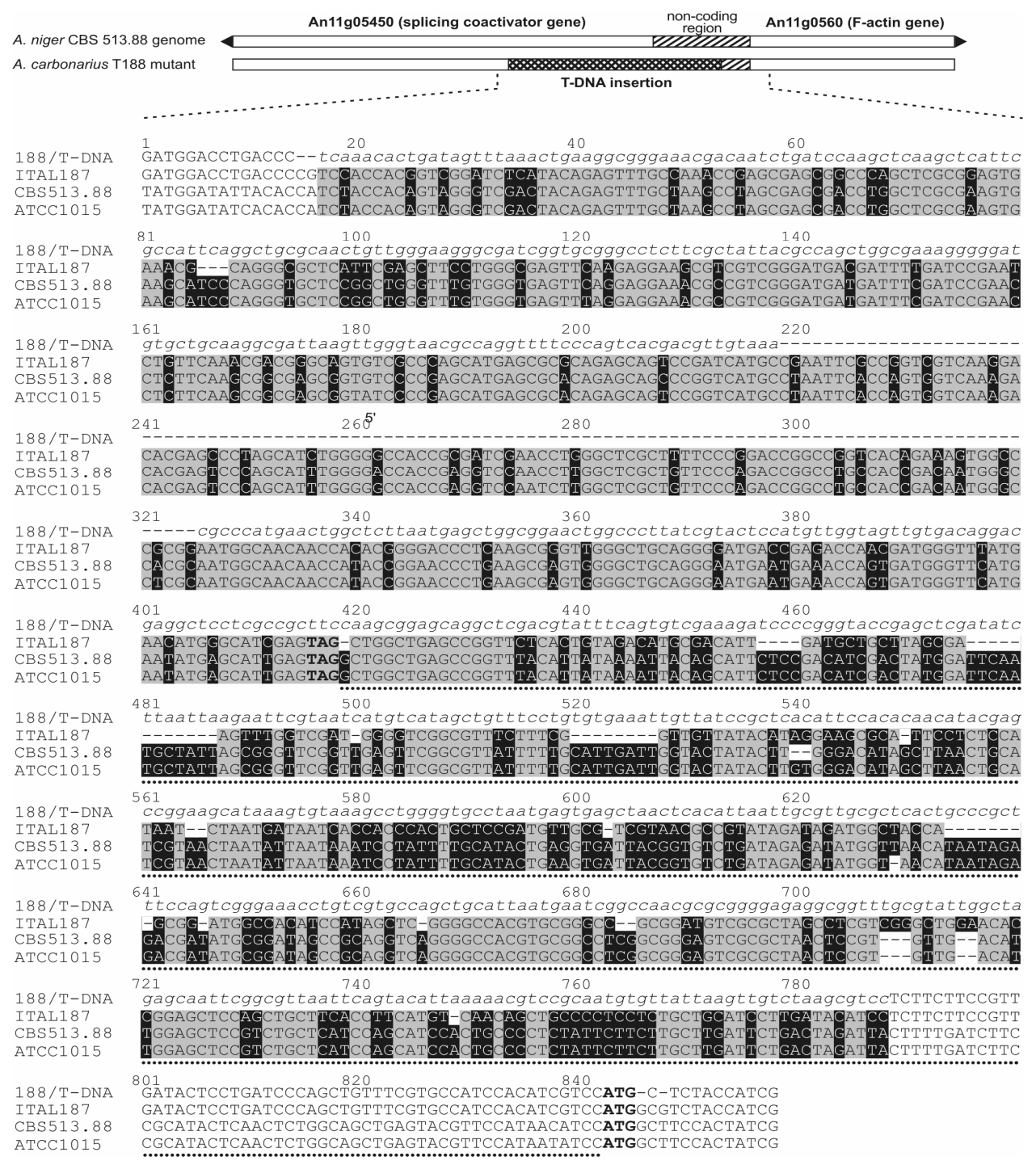

Figure 4 - Alignment of the nucleotide sequences of Aspergillus niger (CBS 513.88 and ATCC 1015 strains), A. carbonarius wild type (ITAL187), and the mutant (T188/T-DNA). The T-DNA integration into the T188 mutant caused a deletion of $727 \mathrm{bp}$ which includes the end of the splicing coactivator gene and a non-coding region (shaded region, the conserved nucleotides are in gray). The non-coding region is represented by $\bullet \bullet \bullet$. The F-actin gene was not affected by integration. The T-DNA sequence is in italic. The stop codon of splicing coactivator gene (TAG) and start codon of F-actin gene (ATG) in $A$. niger are in bold.

Because the mutant T188 has a deletion of the final portion of the splicing coactivator gene and it produces significantly smaller amounts of OTA than the wild type strain, we investigated the possible association between the amount of OTA and transcription levels of the gene being studied. Based on the kinetics of OTA production (Fig. 5), the $4^{\text {th }}$ day was chosen as the point for extracting total RNA and OTA quantification. The wild type strain (ITAL 187) was grown in four different media, CY, YES, PD, and EMP. The highest amount of OTA was detected in CY medium (272 $\left.\mathrm{ng} \mathrm{mL}^{-1}\right)$. After growing on both YES and PD media, the production of OTA was significantly 
lower than that observed in $\mathrm{CY}, 135$ and $118 \mathrm{ng}$ $\mathrm{mL}^{-1}$, respectively. As expected, production of OTA after growing on EMP medium was very low (4.7 $\mathrm{ng} \mathrm{mL} \mathrm{m}^{-1}$ ). The relative expression of the splicing coactivator gene in the four different media was analyzed and an association between the amount of OTA and the transcript levels was observed (Fig. 6). A high Pearson correlation coefficient was found (0.96), showing a supposed involvement of this gene in the production of OTA.

In general the genes involved in the biosynthesis of secondary metabolites are clustered, as already described for aflatoxin/sterigmatocystin (Brown et al., 1996), lovastatin (Kennedy et al., 1999), trichothecenes (Brown et al., 2001), and for gibberellins (Tudzynski and Holter, 1998). In most cases, transcriptional regulation is governed by a pathway-specific DNA-binding protein encoded by a gene located within the cluster (Keller et al., 2005). Analysis of the genomic context of A. niger near the splicing coactivator gene revealed that it was not located within a cluster expected for OTA biosynthesis. No genes assumed to be necessary for OTA production, i.e. encoding polyketide synthases, chloroperoxidase, reductase, esterase, and dehydratase, were found near the splicing coactivator gene. However, some genes that are not located in the gene cluster have also been described as affecting the biosynthesis of some mycotoxins. A typical example is four Fusarium verticillioides genes that are located outside the fumonisin gene cluster but affect fumonisin biosynthesis (Shim and Woloshuk, 2001; Flaherty et al., 2003; Flaherty and Woloshuk, 2004; Bluhm and Woloshuk, 2006).

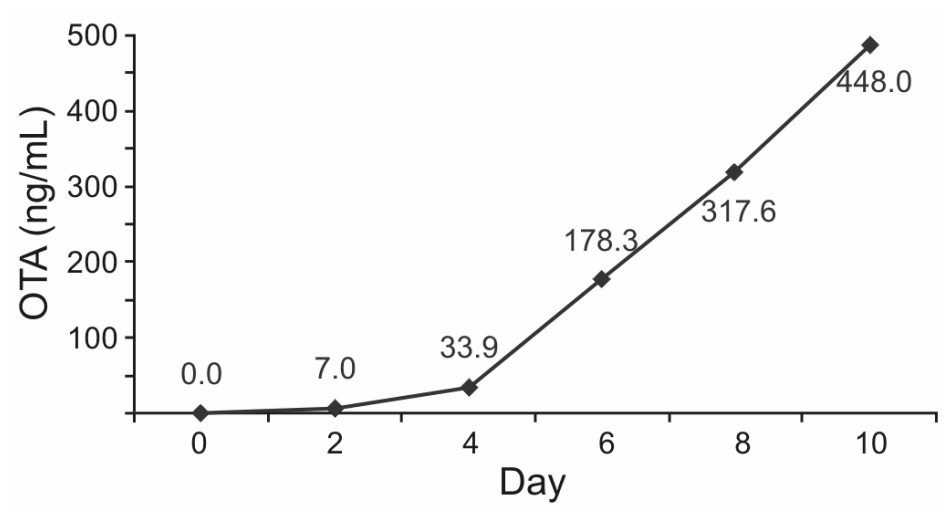

Figure 5 - Kinetic of ochratoxin A production by Aspergillus carbonarius ITAL187 wild type in CY medium.

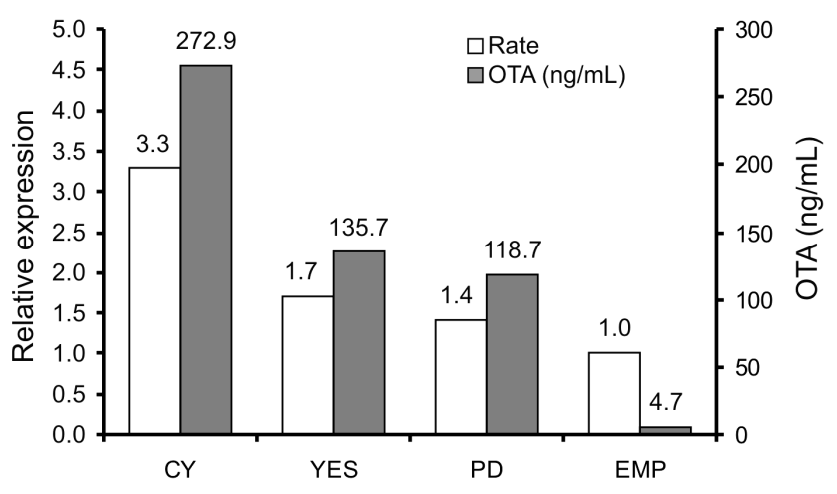

Figure 6 - Association between the transcription levels of the splicing coativator gene and the amount of OTA produced by Aspergillus carbonarius wild type (ITAL187) in four different media, CY, YES, PD, and EMP. 
An analysis of the genes within the $F$. verticillioides fumonisin cluster showed the presence of alternative splicing forms (ASFs) for eight genes, including FUM1, FUM11, and FUM12, that code for polyketide synthase, tricarboxylate carrier and cytochrome P450 monooxigenase, respectively (Brown et al., 2005), and the gene FUM21 which has a $\mathrm{Zn}(\mathrm{II})_{2} \mathrm{Cys}_{6}$ DNA-binding motif, supposedly involved in the transcriptional regulation of the genes in the fumonisin cluster (Brown et al., 2007). The differential expression of the ASFs of FUM genes suggests that splicing regulation can play a role in fumonisin biosynthesis (Brown et al., 2005). Some proteins that participate in the splicing mechanism show serine- and argenine-rich domains, known as RS domains. These proteins play a dual role in the splicing process, affecting both constitutive and alternative splicing and they therefore have a key role in genic expression at the RNA processing level (Fu, 1995). In mammals, the SRm160/300 protein is related to spliceosome formation and plays a part in the recognition of exonic splicing enhancers (ESEs). Both subunits SRm300 and SRm160 have RS domains, but do not show RNA recognition motifs (RRMs) (Blencowe et al., 2000). The splicing coactivador gene, identified in this work, displayed similarities to gene An11g05450 of A. niger CBS 513.88, which amino acid-derived sequence has no RRMs, but does have a serine-rich domain (annotation KEGG at http://www.uniprot.org).

In conclusion, although the splicing coactivator gene identified in this study is not found in an ochratoxin gene cluster, it is in fact associated with the production of OTA.

\section{ACKNOWLEDGMENTS}

Our study was supported (grants and fellowships) by the following Brazilian institutions: Fundação Araucária, Conselho Nacional de Pesquisa (CNPq), Financiadora de Estudos e Projetos (FINEP), and Coordenadoria de Aperfeiçoamento de Pessoal do Ensino Superior (CAPES). Rede Integrada de Biotecnologia Aplicada ao Desenvolvimento Sustentável da Agricultura Familiar no contexto do Agro-negócio Paranaense (BIOAGROPAR) and Laboratório de Apoio à Pesquisa Agropecuária (LAPA).

\section{RESUMO}

A ocratoxina A é uma micotoxina frequentemente encontrada em uma grande variedade de produtos alimentares e apresenta efeitos nefrotóxicos e potencial carcinogênico para animais e humanos. É naturalmente produzida por algumas espécies fúngicas, como Aspergillus carbonarius, que é considerado um potente produtor. Apesar disso, o número de estudos que visam identificar genes que são essenciais para a biossíntese de ocratoxina em A. carbonarius é ainda reduzido. Um mutante de A. carbonarius com baixa produção de ocratoxina A previamente obtido por transformação mediada por Agrobacterium tumefaciens foi investigado com o objetivo de encontrar uma associação entre o gene interrompido e a biossíntese desta micotoxina. Os resultados mostraram a ocorrência de uma junção não exata entre o T-DNA e o DNA genômico do fungo durante $\mathrm{o}$ evento de integração. A integração do T-DNA no genoma do mutante T188 provocou deleção de 727 nucleotídeos. Esta deleção inclui uma porção final do gene coativador de splicing e uma região nãocodificante entre este gene e o gene F-actina. A expressão relativa do gene coativador de splicing na linhagem selvagem cultivada em quatro diferentes meios mostrou associação entre a quantidade de ocratoxina $\mathrm{A}$ e os níveis dos transcritos.

\section{REFERENCES}

Altschul, S. F., Madden, T. L., Schäffer, A. A., Zhang, J., Zhang, Z., Miller, W., Lipman, D. J. (1997), Gapped BLAST and PSI-BLAST: a new generation of protein database search programs. Nucleic Acids Res., 25, 3389-3402.

Atoui, A., Dao, P., Mahieu, F., Lebrihi, A. (2006), Amplification and diversity analysis of ketosynthase domains of putative polyketide synthase genes in Aspergillus ochraceus and Aspergillus carbonarius producers of ochratoxin A. Mol Nutr Food Res., 50, 488-493.

Azevedo, A. C. S., Furlaneto, M. C., Sosa-Gomez, D. R., Fungaro, M. H. P (2000), Molecular characterization of Paecilomyces fumoroseus (Deuteromycotina Hyphomycetes) isolates. Sci Agric. (Piracicaba, Braz.), 57, 729-732.

Azpiroz-Leehan, R., Feldmann, K. A. (1997), T-DNA insertion mutagenesis in Arabidopsis: going back and forth. Trends Genet., 13, 152-156. 
Blencowe, B. J., Baurén, G., Eldridge, A. G., Issner, R., Nickerson, J. A., Rosonina. E., Sharp, P. A. (2000), The SRm160/300 splicing coactivator subunits. RNA, 6, 111-120.

Bluhm, B. H., Woloshuk, C. P. (2006), Fck1, a C-type cyclin-dependent kinase, interacts with $F c c l$ to regulate development and secondary metabolism in Fusarium verticillioides. Fungal Genet Biol., 43, 146154.

Bogs, C., Battilani, P., Geisen, R. (2006), Development of a molecular detection and differentiation system for ochratoxin A producing Penicillium species and its application to analyse the occurrence of Penicillium nordicum in cured meats. Int J Food Microbiol., 107, 39-47.

Brown, D. W., Yu, J.-H., Kelkar, H. S., Fernandes, M., Nesbitt, T. C., Keller, N. P., Adams, T. H., Leonard, T. J. (1996), Twenty-five co-regulated transcripts define a sterigmatocystin gene cluster in Aspergillus nidulans. Proc Natl Acad Sci USA, 93, 1418-1422.

Brown, D. W., McCormick, S. P., Alexander, N. J., Proctor, R. H., Desjardins, A. E. (2001), A genetic and biochemical approach to study trichothecene diversity in Fusarium sporotrichioides and Fusarium graminearum. Fungal Genet Biol., 32, 121-144.

Brown, D. W., Cheung, F., Proctor, R. H., Butchko, R. A. E., Zheng, L., Lee, Y., Utterback, T., Smith, S., Feldblyum, T., Glenn, A. E., Plattner, R. D., Kendra, D. F., Town, C. D., Whitelaw, C. A. (2005), Comparative analysis of 87,000 expressed sequence tags from the fumonisin-producing fungus Fusarium verticillioides. Fungal Genet Biol., 42, 848-861.

Brown, D. W., Butchko, R. A. E., Busman, M., Proctor, R. H. (2007), The Fusarium verticillioides FUM gene cluster encodes a $\mathrm{Zn}(\mathrm{II})_{2} \mathrm{Cys}_{6}$ protein that affects FUM gene expression and fumonisin production. Eukaryot Cell, 6, 1210-1218.

Bundock, P., Dulk-Ras, A., Beijersbergen, A., Hooykaas, P. J. (1995), Trans-kingdom T-DNA transfer from Agrobacterium tumefaciens to Saccharomyces cerevisiae. EMBO J., 14, 3206-3214.

Choi, J., Park, J., Jeon, J., Chi, M. H., Goh, J., Yoo, S. Y., Park, J., Jung, K., Kim, H., Park, S. Y., Rho, H. S., Kim, S., Kim, B. R., Han, S. S., Kang, S., Lee, Y. H. (2007), Genome-wide analysis of T-DNA integration into the chromosomes of Magnaporthe oryzae. Mol Microbiol., 66, 826-826.

Combier, J. P., Melayah, D., Raffier, C., Gay, G., Marmeisse, R. (2003), Agrobacterium tumefaciensmediated transformation as a tool for insertional mutagenesis in the symbiotic ectomycorrhizal fungus Hebeloma cylindrosporum. FEMS Microbiol Lett., 220, 141-148.
Cottage, A., Yang, A., Maunders, H., Lacy, C., Ramsay, N. (2001), Identification of DNA sequences flanking T-DNA insertions by PCR-walking. Plant Mol Biol Rep., 19, 321-327.

Da Rocha Rosa, C. A., Palacios, V., Combina, M., Fraga, M. E., Rekson, A. O., Magnoli, C. E., Dalcero, A. M. (2002), Potential ochratoxin A producers from wine grapes in Argentina and Brazil. Food Addit Contam., 19, 408-414.

European Commission (2005), Commission Regulation (EC) No 123/2005 of 26 January 2005 amending Regulation (EC) No 466/2001 as regards ochratoxin A. Off $J$ Eur Union, L25, 3-5.

Flaherty, J. E., Pirttila, A. M., Bluhm, B. H., Woloshuk, C. P. (2003), PAC1, a pH-regulatory gene from Fusarium verticillioides. Appl Environ Microbiol., 69, 5222-5227.

Flaherty, J. E., Woloshuk C. P. (2004), Regulation of fumonisin biosynthesis in Fusarium verticillioides by a zinc binuclear cluster-type gene, ZFR1. Appl Environ Microbiol., 70, 2653-2659.

$\mathrm{Fu}$, X. D. (1995), The superfamily of arginine/serinerich splicing factors. RNA, 1, 663-680.

Fujii, S., Ono, E.Y.S., Ribeiro, R.M.R., Assunção, F.G.A., Takabayashi, C.R., Oliveira, T.C.R.M., Itano, E.N., Ueno, Y., Kawamura, O., Hirooka, E.Y. A comparison between enzyme immunoassay and HPLC for ochratoxin A detection in green, toasted and instant coffee. Braz. Arch. Biol. Tech., 50, 349359, 2007.

Gallo, A., Perrone, G., Solfrizzo, M., Epifani, F., Abbas, A., Dobson, A. D. W., Mulè, G. (2009), Characterisation of a pks gene which is expressed during ochratoxin A production by Aspergillus carbonarius. Int J Food Microbiol., 129, 8-15.

Geisen, R., Mayer, Z., Karolewiez, A., Färber, P. (2004), Development of a real time PCR system for detection of Penicillium nordicum and for monitoring ochratoxin A production by targeting the ochratoxin A polyketide synthase gene. Syst Appl Microbiol., 27, 501-507.

Karolewiez, A., Geisen, R. (2005), Cloning a part of the ochratoxin A biosynthetic gene cluster of Penicillium nordicum and characterization of the ochratoxin polyketide synthase gene. Syst Appl Microbiol., 28, 588-595.

Keller, N., Turner, G., Bennett, W. J. (2005), Fungal secondary metabolism - from biochemistry to genomics. Nat Rev., 3, 937-947.

Kennedy, J., Auclair, K., Kendrew, S. G., Park, C., Vederas, J. C., Hutchinson, C. R. (1999), Modulation of polyketide synthase activity by accessory proteins during lovastatin biosynthesis. Science, 284, 13681372 . 
Leclerque, A., Wan, H., Abschütz, A., Chen, S., Mitina, G. V., Zimmermann, G., Schairer, H. U. (2004), Agrobacterium-mediated insertional mutagenesis (AIM) of the entomopathogenic fungus Beauveria bassiana. Curr Genet., 45, 111-119.

Li, G., Zhou, Z., Liu, G., Zheng, F., He, C. (2007), Characterization of T-DNA insertion patterns in the genome of rice blast fungus Magnaporthe oryzae. Curr Genet., 51, 233-243.

Lunardi, L. U., Fier, C. B., Ashikaga, F. Y., Morioka, L. R., Fungaro, M. H. P. (2006), Obtenção de mutantes de Aspergillus carbonarius via transformação genética mediada por Agrobacterium tumefaciens. Semina, 27, 95-104.

Macdonald, S., Wilson, P., Barnes, K., Damant, A., Massey, R., Mortby, E., Shepherd, M. J. (1999), Ochratoxin A in dried vine fruit: method development and survey. Food Addit Contam., 16, 253-260.

Majerus, R., Bresch, H., Otteneder, H. (2000), Ochratoxin A in wines, fruit juices and seasonings. Arch Lebensmittelhyg., 51, 95-97.

Meng, Y., Patel, G., Heist, M., Betts, M. F., Tucker, S. L., Galadima, N., Donofrio, N. M., Brown, D., Mitchell, T. K., Li, L., Xu, J. R., Orbach, M., Thon, M., Dean, R. A., Farman, M. L. (2007), A systematic analysis of T-DNA insertion events in Magnaporthe oryzae. Fungal Genet Biol., 44, 1050-1064.

Morioka, L. R. I., Furlaneto, M. C., Bogas, A. C., Pompermayer, P., Duarte, R. T. D., Vieira, M. L. C., Watanabe, M. A. E., Fungaro, M. H. P (2006), Efficient genetic transformation system for the ochratoxigenic fungus Aspergillus carbonarius. Curr Microbiol., 52, 469-472.

Moss, M. O. (1996), Mode of formation of ochratoxin A. Food Addit Contam., 13, 5-9.

Mullins, E. D., Chen, X., Romaine, P., Raina, R., Geiser, D. M., Kang, S. (2001), Agrobacteriummediated transformation of Fusarium oxysporum: an efficient tool for insertional mutagenesis and gene transfer. Phytopathology, 91, 173-180.

O'Callaghan, J., Caddick, M. X., Dobson, A. D. (2003), A polyketide synthase gene required for ochratoxin A biosynthesis in Aspergillus ochraceus. Microbiology., 149, 3485-3491.
O’Callaghan, J., Dobson, A. D. W. (2006a), Molecular characterization of ochratoxin A biosynthesis and producing fungi. Adv Appl Microbiol., 58, 227-243.

O’Callaghan, J., Stapleton, P. C., Dobson, A. D. W. (2006b), Ochratoxin A biosynthetic genes in Aspergillus ochraceus are differentially regulated by $\mathrm{pH}$ and nutricional stimuli. Fungal Genet Biol., 43, 213-221.

Pfaffl, M. W., Graham, W. H., Dempfle, L. (2002), Relative expression software tool $\left(\mathrm{REST}^{\odot}\right.$ ) for groupwise comparison and statistical analysis of relative expression results in real-time PCR. Nucleic Acids Res., 30, 2-10.

Radhamony, R. N., Prasad, A. M., Srinivasan, R. (2005), T-DNA insertional mutagenesis in Arabidopsis: a tool for functional genomics. Electron J Biotechnol., 8, 82-106.

Sambrook, J., Russel, D. W. (2001), Preparation and analysis of eukaryotic genomic DNA. In-Molecular cloning: a laboratory manual, 3rd ed. Cold Spring Harbor Laboratory Press, Cold Spring Harbor, New York, pp. 237-268.

Shim, W. B., Woloshuk, C. P. (2001), Regulation of fumonisin B1 biosynthesis and conidiation in Fusarium verticillioides by a cyclin-like (C-type) gene, FCC1. Appl Environ Microbiol., 67, 16071612.

Taniwaki, M. H., Pitt, J. I., Teixeira, A. A., Iamanaka, B. T. (2003), The source of ochratoxin A in Brazilian coffee and its formation in relation to processing methods. Int J Food Microbiol., 82, 173-179.

Tudzynski, B., Holter, K. (1998), Gibberellin biosynthetic pathway in Gibberella fujikuroi: evidence for a gene cluster. Fungal Genet Biol., 25, 157-170.

Valero, A., Marín, S., Ramos A. J., Sanchis, V. (2005), Ochratoxin A-producing species in grapes and sundried grapes and their relation to ecophysiological factors. Lett Appl Microbiol., 41, 196-201.

Zimmerli, B., Dick, R. (1996), Ochratoxin A in table wine and grape-juice: occurrence and risk assessment. Food Addit Contam., 13, 655-668. 


\section{Página Em \\ Branco}

